\title{
EFFECTS OF RATES AND NUTRIENT RATIOS ON PRODUCTION AND QUALITY OF PHYTOMASS AT FERTILISER APPLICATION TO AN ALLUVIAL MEADOW
}

\author{
VLADIMÍRA VARGOVÁ, ZUZANA KOVAČIKOVÁ, MILAN MICHALEC
}

Plant Production Research Center Piešt'any

VARGOVÁ, V. - KOVAČIKOVÁ, Z. - MICHALEC, M.: Effects of rates and nutrient ratios on production and quality of phytomass at fertiliser application to an alluvial meadow. Agriculture (Pol’nohospodárstvo), vol. 58, 2012, no. 1, pp. 1-10.

The research objective was to assess effects of fertiliser
application rates and nutrient ratios on production and quality
of grassland at an alluvial meadow. The initial sward type was
Festucetum pratense association. A field trial was established in
the western part of "Zvolenská kotlina" basin (altitude $350 \mathrm{~m}$ )
and consisted of ten fertiliser treatments: zero-fertilised sward
(control); fertiliser P and $\mathrm{K}$ application; rates of $50,100,150$
and $200 \mathrm{~kg} \mathrm{~N} / \mathrm{ha}$ at two ratios of $\mathrm{N}: \mathrm{P}: \mathrm{K}$ nutrients, name-
ly the $1 \mathrm{w} \mathrm{N}: \mathrm{P}: \mathrm{K}$ ratio $(1: 0.3: 0.8)$ and the high one
$(1: 0.15: 0.4)$, respectively. The grassland was utilised by
three cuts. Dry matter (DM) production and herbage quality
were determined at each of the cuts. The yield of DM was hi-
gher with the rates of 50 and $100 \mathrm{~kg} \mathrm{~N} / \mathrm{ha}$ applied at the high
nutrient ratio than at the low ratio. Over the research peri-
od, the highest DM production was recorded at the treatment with the low nutrient ratio and the highest $\mathrm{N}$ rate applied. The content of crude protein $(\mathrm{CP})$ was increasing with the rising fertiliser $\mathrm{N}$ rate and the increase in $\mathrm{CP}$ was higher at the low nutrient ratio treatments. The zero-fertilised control also provided sufficient $\mathrm{CP}$ content. The low nutrient ratio resulted in higher $\mathrm{P}$ and $\mathrm{K}$ content than the high one. The lowest content of $\mathrm{P}$ and $\mathrm{K}$ was recorded at the control. The highest $\mathrm{P}$ content was found at the treatment with the fertiliser $\mathrm{P}$ and $\mathrm{K}$ applied. The highest $\mathrm{K}$ content was recorded at the $2^{\text {nd }}$ cut, but decreased at the $3^{\text {rd }}$ cut in all the treatments. The content of $\mathrm{Ca}$ was rising towards the $3^{\text {rd }}$ cut. The content of nutrients was higher at the treatments where the high ratio was used. The content of $\mathrm{Mg}$ in DM was higher at the treatments with the high nutrient ratio and the high $\mathrm{N}$ fertiliser rates. The content of $\mathrm{Mg}$ was increasing in the $2^{\text {nd }}$ cut at all the treatments.

Key words: alluvial meadow, long-term fertilising, herbage quality, production, permanent grassland

The fertiliser application ranks among the factors intensifying improvement of permanent grassland and is decisive not only for good yield and quality of forage, but also for good condition and long life of sward (Rataj 1996). The level of fertilising has a notable impact on the botanical composition and consequently, on the quantitative and qualitative aspects of production. Compared to arable crops, grassland nutrition has some peculiarities, e.g. a considerable amount of organic residues in soil is a rich source of released available nutrients; different ability of roots to take nutrients from more or less accessible forms; high number of symbiotic plants; dense representation of micro- and macro-edaphone not only supports, but also intensifies the effects of fertiliser application. Overall success of fertilisation depends on the initial state of grassland, the availability of water, the soil and climatic conditions, the method and frequency of utilisation and on the length of time over which the fertiliser is applied systematically (Slamka et al. 2006). The systematic and relatively long-term intensive application of nitrogen $(\mathrm{N})$ fertiliser increases herbage and dry matter (DM) yields only during a limited period of time which is followed by sward degradation, decreased yields and the fertilisation ceases to be effective and economic (Rataj 1996).

Ing. Vladimíra Vargová, Ing. Zuzana Kovačiková, Ing. Milan Michalec, CSc., Plant Production Research Center - Grassland and Mountain Agriculture Research Institute, 97421 Banská Bystrica, Mládežnícka 36, Slovak Republic. E-mail: vargova@vutphp.sk 
The content of crude protein $(\mathrm{CP})$ is much higher in $\mathrm{DM}$ of leaves than in that of stems and moreover, it is also higher in legumes than in grasses. The application of high $\mathrm{N}$ fertiliser rates (more than $120 \mathrm{~kg} / \mathrm{ha}$ ) eliminates these differences and the $\mathrm{CP}$ content in grass may exceed the amount of CP in legumes (Holúbek et al. 2001).

The presented research aimed at studying the quality and production of herbage from an alluvial meadow at different fertiliser rates and nutrient ratios used the during fertiliser application.

\section{MATERIAL AND METHODS}

The research site "Vel'ká Lúka" (altitude $350 \mathrm{~m}$; northern latitude $48^{\circ} 37^{\prime}$; eastern longitude $19^{\circ} 10^{\prime}$ ) was located in the protection zone of "Sliač" spa, in the western part of "Zvolenská kotlina" basin. The edaphic conditions at the research site were as follows: geological substratum - the alluvial soil was loamy fluvisol; initial soil $\mathrm{pH}$ in $\mathrm{KCl}=6.03$; available nutrients: $\mathrm{P}=6.16 \mathrm{mg} / \mathrm{kg}$ and $\mathrm{K}=96.6 \mathrm{mg} / \mathrm{kg}$. The initial sward type was Festucetum pratense association with 35 species (Alopecurus pratensis dominant) at the trial start (Table 2). Long-term mean rainfall over growing season is $428 \mathrm{~mm}$; long-term mean annual rainfall $757 \mathrm{~mm}$; mean daily temperature $8.2^{\circ} \mathrm{C}$ per year and $14.7^{\circ} \mathrm{C}$ over growing season (Figure 1 ).

The field trial has been established as randomised blocks with four replicates (plot size $32 \mathrm{~m}^{2} ; 8 \times 4 \mathrm{~m}$ ) in 1961. This paper presents the research period of 2006
2009. The trial comprised the following 10 treatments (Table 1) with a range of fertiliser application rates: Treatment 1: zero-fertilised sward (control); Treatment 2: fertiliser $\mathrm{P}$ and $\mathrm{K}$ application; Treatments 3, 4, 5 and 6: fertiliser $\mathrm{N}, \mathrm{P}$ and $\mathrm{K}$ application at the $\mathrm{N}: \mathrm{P}: \mathrm{K}$ ratio of $1: 0.30: 0.8$, respectively; Treatments $7,8,9$ and 10: fertiliser $\mathrm{N}, \mathrm{P}$ and $\mathrm{K}$ application at the $\mathrm{N}: \mathrm{P}$ : $\mathrm{K}$ ratio of $1: 0.15: 0.4$, respectively. The trial treatments and the fertiliser application rates in detail are given in Table 1. The fertiliser nitrogen was applied as ammonium nitrate (LAD 27\%), $\mathrm{P}$ was applied as "hyperkorn" (8.5\%) and K as potassium salt (52.23\%). The total rate of $\mathrm{N}$ fertiliser was split into two dressings which were applied in the early spring (65\%) and after the $1^{\text {st }}$ cut $(35 \%)$.

Grassland was utilised by three cuts a year: the $1^{\text {st }}$ cut - at the ear emergence of dominant grass species; the $2^{\text {nd }}$ cut - approximately 6 to 8 weeks later; the $3^{\text {rd }}$ cut - approximately 8 to 10 weeks after the $2^{\text {nd }}$ cut.

The dry matter (DM) production was determined as follows: fresh herbage was weighed at the research site, DM content was determined in herbage (at $105^{\circ} \mathrm{C}$ ) and the yield of DM was calculated per hectare. The herbage samples were oven-dried at $65^{\circ} \mathrm{C}$ and submitted to the chemical analysis to determine the content of nutrients (crude protein - Kjeldahl method $(\mathrm{N} \times 6.25)$, content of $\mathrm{P}, \mathrm{K}, \mathrm{Mg}$ were determined in accordance with the Slovak technical standard STN 46 7093. The obtained data were subjected to analysis of variance (ANOVA) followed by post hoc comparison using the Tukey's HSD test (Statit Custom QC for Windows).

$\mathrm{T}$ a $\mathrm{b} 1 \mathrm{e} 1$

Trial treatments

\begin{tabular}{|c|c|c|c|c|c|c|c|c|c|c|}
\hline Treatments & 1 & 2 & 3 & 4 & 5 & 6 & 7 & 8 & 9 & 10 \\
\hline $\begin{array}{c}\text { Nutrient } \\
\text { rates } \\
{[\mathrm{kg} / \mathrm{ha}]}\end{array}$ & 0 & PK & \multicolumn{4}{|c|}{$1: 0.30: 0.8$} & \multicolumn{4}{|c|}{$1: 0.15: 0.4$} \\
\hline $\mathrm{N}$ & 0 & 0 & 50 & 100 & 150 & 200 & 50 & 100 & 150 & 200 \\
\hline$P$ & 0 & 22 & 15 & 30 & 45 & 60 & 7.5 & 15 & 22.5 & 30 \\
\hline K & 0 & 41.5 & 40 & 80 & 120 & 160 & 20 & 40 & 60 & 80 \\
\hline
\end{tabular}




\section{RESULTS AND DISCUSSION}

Over the growing seasons of the research period, mean air temperature was rising from $15.98^{\circ} \mathrm{C}$ in 2006 to $17.06^{\circ} \mathrm{C}$ in 2009 , except for the year 2008 when the mean temperature was $0.02^{\circ} \mathrm{C}$ lower than in 2006, especially in the cool months of April and September, as given in Figure 1. Total monthly rainfall over the growing seasons decreased in 2006 and 2007, then increased to $389 \mathrm{~mm}$ in 2008 and decreased by $74 \mathrm{~mm}$ in 2009. The rainfall was extremely low in April in 2007 $(0 \mathrm{~mm})$ and $2009(9 \mathrm{~mm})$, respectively. Only in June 2009 the rainfall over growing season increased.

Table 3 and Figure 2 present the yields of dry matter and increments of DM yields throughout the research period of 2006-2009. In 2008, the lowest DM yield was recorded at all the treatments, due to the rainfall deficiency in the early (April, May) and in the late months (August, September) of growing season. The Treatment 1 (control) was characterised by low DM production (2.63-4.91 t/ha).

By comparison with the control, the fertiliser $\mathrm{P}$ and $\mathrm{K}$ application increased yields in all the cuts and years, except in 2009 (Table 3). The highest increase was recorded at the $2^{\text {nd }}$ cut in 2006 (more by $1.07 \mathrm{t} / \mathrm{ha}$ than Treatment 1 - the control). In 2007 and 2009, the DM yields decreased at the $2^{\text {nd }}$ and $3^{\text {rd }}$ cuts. Holúbek et al. (2007), Honsová et al. (2007) and Jančovič et al. (2009) reported that the fertiliser P and K application itself increased the yield variability, mainly as a result of higher variability in the proportion of grasses and legumes in sward at the cuts.

The application of nitrogen significantly increased the DM production nearly in all the cuts and years $(P<0.01)$ and influenced also the total yield over the research period (Table 6). The variability in the yield increase under the rising $\mathrm{N}$ rates was found in agreement with Velich (1986), Holúbek (1991), Glaba and Kacorzykb (2011) and other authors studying the grassland nutrition.

An exception was found at the $2^{\text {nd }}$ cut in 2007 when the highest DM production was recorded at the zerofertilised control. Over the given period, the significantly highest DM production $(P<0.01)$ was recorded at Treatment 6 with the highest $\mathrm{N}$ rate and the low nutrient ratio applied (Table 6). The highest total DM yield for the whole research period was also found at Treatment 6 in all the years, except for the year 2006, when the lowest DM yield (5.7 t/ha) was recorded there. In the years 2006, 2008 and 2009, respectively, the application rate of $50 \mathrm{~kg} \mathrm{~N} / \mathrm{ha}$ with the low nutrient ratio resulted in higher DM production at Treatment 3 than at the comparable Treatment 7 with the high ratio of nutrients. With the high $\mathrm{N}$ rate $(100 \mathrm{~kg} / \mathrm{ha})$ and the high nutrient ratio (Treatment 8 ), the DM yield was higher than that at Treatment 4 with the low nutrient ratio. This was not the case in 2008 when the production of DM was $4.61 \mathrm{t} / \mathrm{ha}$ at Treatment 8 ,

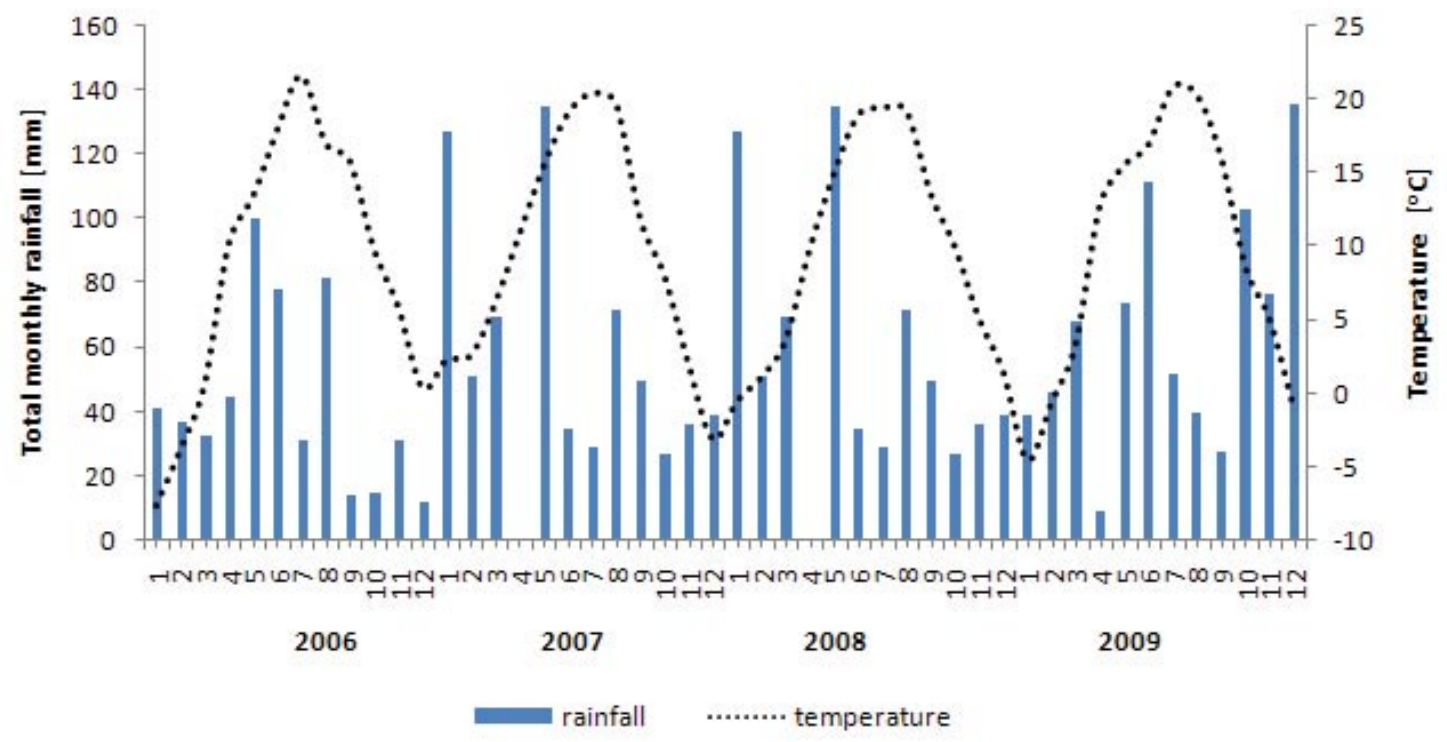

Figure 1. Mean monthly temperature $\left[{ }^{\circ} \mathrm{C}\right]$ and total monthly rainfall $[\mathrm{mm}]$ at "Vel'ká Lúka" site 


\section{$\mathrm{T}$ a $\mathrm{b} 1 \mathrm{e} 2$}

Botanical composition [\%] at the $1^{\text {st }}$ cut in 2006

\begin{tabular}{|c|c|c|c|c|c|c|c|c|c|c|}
\hline \multirow{2}{*}{ Botanical composition } & \multicolumn{10}{|c|}{ Treatments* } \\
\hline & 1 & 2 & 3 & 4 & 5 & 6 & 7 & 8 & 9 & 10 \\
\hline Grasses & 50 & 53 & 62 & 68 & 71 & 72 & 49 & 62 & 70 & 54 \\
\hline Legumes & 13 & 8 & 7 & 3 & 5 & 4 & 3 & 4 & 2 & 2 \\
\hline Herbs & 37 & 36 & 31 & 29 & 24 & 24 & 48 & 34 & 28 & 44 \\
\hline Bare ground & 0 & 3 & 0 & 0 & 0 & 0 & 0 & 0 & 0 & 0 \\
\hline Alopecurus pratensis L. & 3 & 5 & 3 & 5 & 6 & 5 & 2 & 5 & 5 & 2 \\
\hline Anthoxanthum odoratum $\mathrm{L}$. & 20 & 20 & 30 & 10 & 10 & 12 & 20 & 26 & 25 & 15 \\
\hline Arrhenatherum elatius L. & - & 8 & 1 & 9 & 15 & 20 & 7 & 7 & 10 & 15 \\
\hline Avenastrum pubescens Dumort. & 1 & - & 1 & 1 & 2 & 1 & 2 & 2 & 3 & 2 \\
\hline Bromus erectus Huds. & - & - & - & - & 1 & - & 1 & - & - & - \\
\hline Carex spp. & 6 & - & 6 & - & - & - & 1 & - & - & - \\
\hline Dactylis glomerata $\mathrm{L}$. & 3 & 2 & 4 & - & 2 & - & - & 3 & 4 & 2 \\
\hline Deschampsia caespitosa (L). P. Beauv. & - & - & - & - & - & - & - & - & - & - \\
\hline Elytrigia repens $L$. & + & - & - & - & - & - & - & - & - & - \\
\hline Festuca pratensis Huds. & 3 & - & - & 2 & 2 & - & - & 2 & - & - \\
\hline Festuca rubra $\mathrm{L}$. & 2 & 5 & - & 3 & 1 & 4 & - & 3 & 2 & 4 \\
\hline Lolium perenne $\mathrm{L}$. & 2 & - & 2 & 1 & - & - & - & - & - & - \\
\hline Phleum pratense $\mathrm{L}$. & - & - & - & - & - & - & - & - & - & - \\
\hline Poа аппиа $\mathrm{L}$. & - & - & - & - & - & - & - & - & - & - \\
\hline Poa pratensis $\mathrm{L}$. & 10 & 10 & 15 & 15 & 22 & 18 & 10 & 8 & 12 & 10 \\
\hline Trisetum flavescens (L.) P. Beauv. & - & 3 & 2 & 22 & 10 & 12 & 6 & 5 & 8 & 4 \\
\hline Lotus corniculatus L. & 3 & - & 1 & - & - & - & - & - & - & - \\
\hline Medicago lupulina $\mathrm{L}$. & - & - & - & - & - & - & - & - & - & - \\
\hline Trifolium repens $\mathrm{L}$. & 7 & 5 & 2 & 1 & 1 & - & 1 & 3 & 1 & 1 \\
\hline Trifolium pratense $\mathrm{L}$. & 3 & 3 & 4 & 2 & 4 & 3 & 2 & 1 & 1 & 1 \\
\hline Vicia tenuifolia $\mathrm{L}$. & - & - & - & - & 1 & - & - & - & - & - \\
\hline Acetosa pratensis Mill. & - & 1 & 2 & 2 & 2 & - & 3 & 2 & 3 & - \\
\hline Achillea millefolium $\mathrm{L}$. & 5 & 6 & 3 & 4 & 2 & 4 & 7 & 4 & 3 & 3 \\
\hline Campanula patula $\mathrm{L}$. & + & - & + & - & - & 1 & + & + & 1 & + \\
\hline Capsella bursa pastoris (L.) Medik. & - & - & - & + & - & - & - & - & - & - \\
\hline Cirsium arvense $\mathrm{L}$. & - & 1 & - & - & - & - & - & - & + & 3 \\
\hline Cirsium canum (L.) Scopp. & - & - & - & - & - & - & - & - & - & - \\
\hline Daucus carota $\mathrm{L}$. & 1 & 4 & - & + & + & 1 & 2 & 1 & 2 & 2 \\
\hline Galium mollugo L. & - & 1 & - & - & - & - & + & 1 & 2 & 3 \\
\hline Geranium pratense $\mathrm{L}$. & - & - & - & - & - & - & + & - & + & - \\
\hline Geranium robertianum $\mathrm{L}$. & - & - & - & - & - & - & - & - & - & - \\
\hline Glechoma hederacea $\mathrm{L}$. & - & - & - & - & + & + & + & 1 & - & 1 \\
\hline Jacea pratensis Lam. & 2 & 1 & 1 & 2 & 1 & - & - & + & - & 2 \\
\hline Leontodon hispidus $\mathrm{L}$. & 10 & 3 & 8 & 5 & 6 & 5 & 10 & 10 & - & 4 \\
\hline Leucanthemum vulgare Lam. & 3 & 3 & 1 & 2 & 1 & 2 & 2 & 1 & 2 & 5 \\
\hline Plantago lanceolata $\mathrm{L}$. & - & 6 & 5 & 4 & 6 & 4 & 12 & 2 & 2 & 5 \\
\hline Plantago major $\mathrm{L}$. & 6 & - & 3 & 2 & 1 & 1 & 2 & 1 & - & - \\
\hline Prunella vulgaris $\mathrm{L}$. & - & - & - & - & - & - & - & - & - & - \\
\hline Ranunculus acris L. & 2 & 3 & 3 & 2 & 2 & 2 & 3 & 4 & 5 & 4 \\
\hline Salvia pratensis $\mathrm{L}$. & - & - & + & - & - & - & - & - & - & - \\
\hline Stellaria graminea $\mathrm{L}$. & - & 3 & 1 & - & + & 1 & 4 & 2 & 2 & 2 \\
\hline Taraxacum officinale auct. non Weber. & 5 & 4 & 2 & 4 & 2 & 2 & 2 & 3 & 4 & 7 \\
\hline Tragopogon orientalis $\mathrm{L}$. & - & - & - & - & - & - & - & + & + & 1 \\
\hline Veronica verna $\mathrm{L}$. & 2 & - & 2 & 2 & 1 & 1 & 1 & 2 & 2 & 1 \\
\hline
\end{tabular}

+less than $1 \%$, *see Table 1 
but it was $4.86 \mathrm{t} / \mathrm{ha}$ at Treatment 4 . Similar results (approx. $5 \mathrm{t} / \mathrm{DM} / \mathrm{ha}$ ), but with the maximum fertiliser rate (240 kg N/ha) were reported by Vozár (2009) from the trial at "Chvojnica" site. There had been reports of DM production decreasing from the $1^{\text {st }}$ to the $3^{\text {rd }}$ cut (Velich 1986). Our research data showed slight variations. In both 2007 and 2009, the DM yield was higher in the $2^{\text {nd }}$ cut than at the $1^{\text {st }}$ one, namely at the non-fertilised control as well as at Treatment $3(50 \mathrm{~kg} \mathrm{~N} / \mathrm{ha}$ and the low nutrient ratio). Based on his trials, Fiala (2002) pointed out that neither the long-term fertiliser application of as much as $300 \mathrm{~kg} \mathrm{~N} / \mathrm{ha}$ nor the grassland utilisation by three cuts disturbed the ecological stability. The DM production rises while the nitrogen fertiliser rate is extended up to $150 \mathrm{~kg} \mathrm{~N} / \mathrm{ha}$ and both the forage quality and production efficiency are increased. The most stabile treatments appear to be those where the low and medium rates of nitrogen fertiliser (50 and $150 \mathrm{~kg} \mathrm{~N} / \mathrm{ha}+\mathrm{PK}$ ) are applied. This conclusion was drawn also in our research. Honsová et al. (2006) had carried out trials on a valley meadow at "Černíkovice" site and consequently, they confirmed the hypothesis of DM yields depending on the amount of nitrogen applied. At the control, mean production of herbage was $2.6 \mathrm{t} \mathrm{ha}^{-1}$ and the highest production $(8.95 \mathrm{t} / \mathrm{ha})$ was recorded at the treatment with the $\mathrm{N}_{200} \mathrm{P}_{40} \mathrm{~K}_{100}$ application rate.

Figure 2 gives the DM increase in comparison to the zero-fertilised control. The highest increase in DM yield (by $138.02 \%$, i.e. $3.63 \mathrm{t} / \mathrm{ha}$ ) was recorded at Treatment 6 in 2008 (200 kg N; low nutrient ratio). Over the research years, high increase in DM yield was recorded at Treatment 3, except for the year 2007 when a decrease by $8.2 \%$ was found. Averaged over the research years and in comparison with the control, the increase in DM was higher at the treatments with identical rates of nitrogen and high ratio of nutrients (19.56 \% at Treatment 7 and $37.92 \%$ at Treatment 8 ) than those with the low nutrient ratio. It was the opposite situation at Treatments 5 and 6 with the high rates of nitrogen fertiliser and the low nutrient ratio (increase by $56.76 \%$ and $64 \%$ ) in comparison with the treatments with the high nutrient ratio (increase by $45.65 \%$ and $57.49 \%$ ).

Hejcman et al. (2010) and Holúbek et al. (2007) reported that the content of nutrients in herbage DM decreased with the reduction of available nutrients in soil and decreased also with increasing yield due to the so called dilution effect in the grown-up biomass. The quality of dry matter is defined by the mineral and organic composition (Whitehead 2000; Lichner et al. 1983).

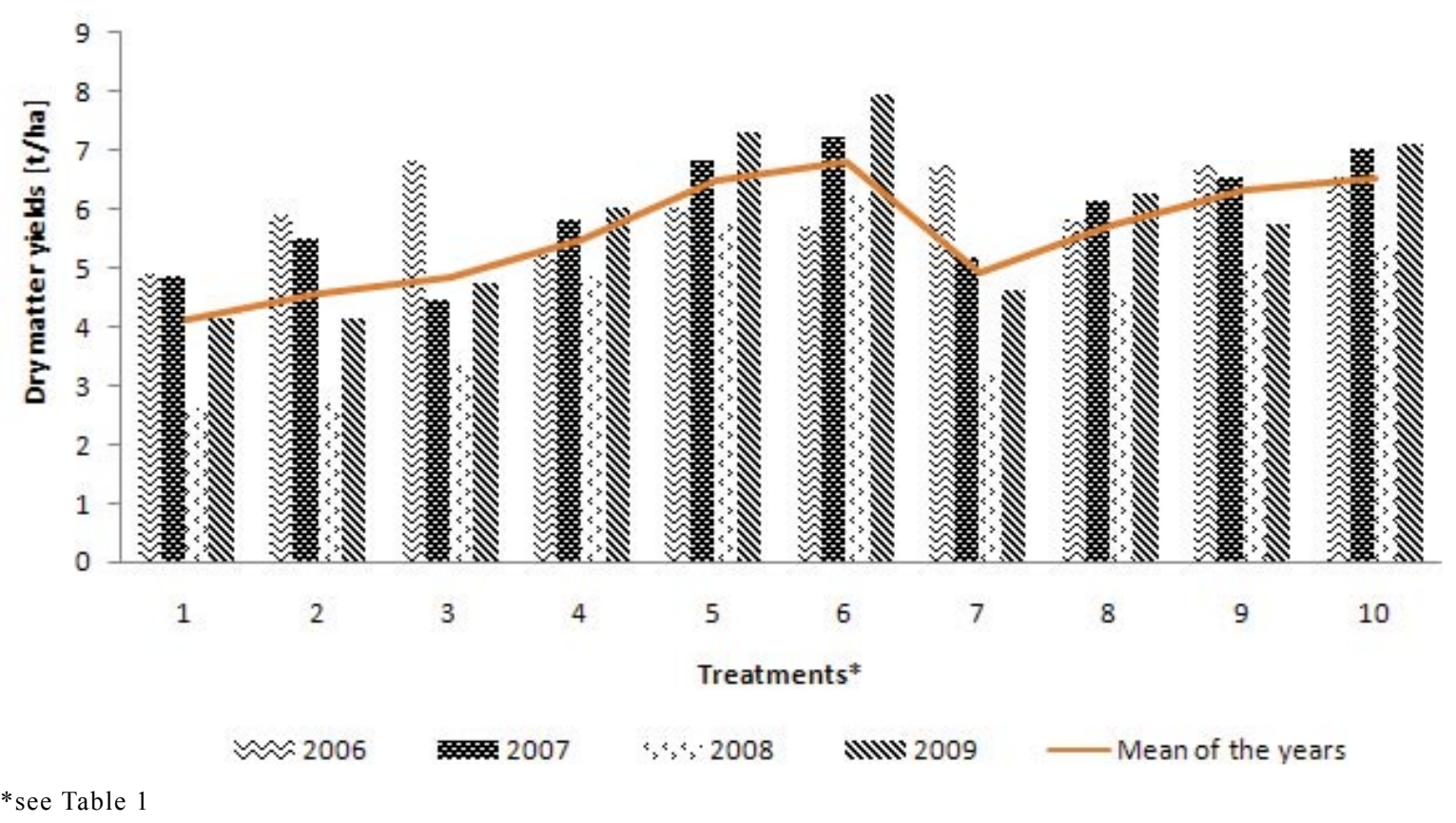

Figure 2. Dry matter yields during 2006-2009 
$\mathrm{T}$ a $\mathrm{b} 1 \mathrm{e} 3$

Dry matter yields $[\mathrm{t} / \mathrm{ha}]$

\begin{tabular}{|c|c|c|c|c|c|c|c|c|c|c|}
\hline \multirow{2}{*}{ Treatments* } & \multirow{2}{*}{$\begin{array}{l}0 \\
1\end{array}$} & \multirow{2}{*}{$\begin{array}{c}\text { PK } \\
2\end{array}$} & \multicolumn{4}{|c|}{$1: 0.30: 0.80$} & \multicolumn{4}{|c|}{$1: 0.15: 0.40$} \\
\hline & & & 3 & 4 & 5 & 6 & 7 & 8 & 9 & 10 \\
\hline \multicolumn{11}{|c|}{2006} \\
\hline $1^{\text {st }}$ cut & 3.07 & 2.62 & 3.88 & 2.23 & 2.59 & 2.22 & 3.80 & 2.60 & 3.40 & 2.84 \\
\hline $2^{\text {nd }}$ cut & 0.92 & 1.99 & 1.86 & 1.81 & 2.27 & 2.17 & 1.50 & 1.99 & 2.27 & 2.60 \\
\hline $3^{\text {rd }}$ cut & 0.92 & 1.31 & 1.10 & 1.18 & 1.17 & 1.31 & 1.46 & 1.23 & 1.07 & 1.12 \\
\hline$\sum$ & 4.91 & 5.92 & 6.84 & 5.22 & 6.03 & 5.70 & 6.76 & 5.82 & 6.74 & 6.56 \\
\hline \multicolumn{11}{|c|}{2007} \\
\hline $1^{\text {st }}$ cut & 0.94 & 2.16 & 1.79 & 2.64 & 3.11 & 3.25 & 1.72 & 2.34 & 3.08 & 3.21 \\
\hline $2^{\text {nd }}$ cut & 2.92 & 2.41 & 1.93 & 2.36 & 2.61 & 2.85 & 2.41 & 2.63 & 2.25 & 2.89 \\
\hline $3^{\text {rd }}$ cut & 1.01 & 0.94 & 0.75 & 0.85 & 1.12 & 1.15 & 1.06 & 1.19 & 1.21 & 0.95 \\
\hline$\sum$ & 4.87 & 5.51 & 4.47 & 5.85 & 6.84 & 7.25 & 5.19 & 6.16 & 6.54 & 7.05 \\
\hline \multicolumn{11}{|c|}{2008} \\
\hline $1^{\text {st }}$ cut & 1.30 & 1.19 & 1.83 & 2.31 & 2.64 & 3.37 & 1.61 & 2.80 & 2.75 & 2.89 \\
\hline $2^{\text {nd }}$ cut & 0.60 & 1.03 & 0.96 & 1.70 & 2.15 & 1.76 & 1.13 & 1.01 & 1.34 & 1.73 \\
\hline $3^{\text {rd }}$ cut & 0.73 & 0.48 & 0.61 & 0.85 & 0.99 & 1.13 & 0.49 & 0.80 & 0.99 & 0.76 \\
\hline$\Sigma$ & 2.63 & 2.70 & 3.40 & 4.86 & 5.78 & 6.26 & 3.23 & 4.61 & 5.08 & 5.38 \\
\hline \multicolumn{11}{|c|}{2009} \\
\hline $1^{\text {st }}$ cut & 1.15 & 1.81 & 1.79 & 2.23 & 2.01 & 2.43 & 1.50 & 2.03 & 1.87 & 2.29 \\
\hline $2^{\text {nd }}$ cut & 2.15 & 1.71 & 2.11 & 2.74 & 4.49 & 4.38 & 2.03 & 2.97 & 2.87 & 3.54 \\
\hline $3^{\text {rd }}$ cut & 0.86 & 0.62 & 0.84 & 1.07 & 0.82 & 1.16 & 1.10 & 1.26 & 1.03 & 1.27 \\
\hline$\sum$ & 4.16 & 4.14 & 4.74 & 6.04 & 7.32 & 7.97 & 4.63 & 6.26 & 5.77 & 7.10 \\
\hline$\sum$ yield over 4 years & 16.57 & 18.27 & 19.45 & 21.97 & 25.97 & 27.18 & 19.81 & 22.85 & 24.13 & 26.09 \\
\hline Mean of the years & $4.14^{\mathrm{a}}$ & $4.59^{\mathrm{ab}}$ & $4.86^{\mathrm{bc}}$ & $5.49^{\mathrm{cd}}$ & $6.49^{\mathrm{e}}$ & $6.79^{\mathrm{e}}$ & $4.95^{\mathrm{bc}}$ & $5.71^{\mathrm{d}}$ & $6.03^{\mathrm{de}}$ & $6.52^{\mathrm{e}}$ \\
\hline SEM & 0.533 & 0.730 & 0.720 & 0.274 & 0.357 & 0.510 & 0.730 & 0.379 & 0.380 & 0.400 \\
\hline
\end{tabular}

The values in the same row with different superscript letters are significantly different at $P<0.01$ level for each variable Tukey's HSD test

SEM - standard error of the mean

* see Table 1

Table 4 shows that the increasing nitrogen rate resulted in rising crude protein content. The highest CP content $(201.68 \mathrm{~g} / \mathrm{kg})$ was found in the $1^{\text {st }}$ cut at Treatment 5 with the rate of $150 \mathrm{~kg} \mathrm{~N} / \mathrm{ha}$ and the low nutrient ratio, but the differences were not significantly different (Table 7). However, the decrease in CP content was very significant $(P<0.01)$ by comparison between the years.

The highest $\mathrm{CP}$ content was recorded mostly at the $1^{\text {st }}$ cut, except for Treatments 1 and 3 to 10 in 2008 and 2009, respectively, when the CP content was higher at the $2^{\text {nd }}$ cut, as shown by the statistically significant effect (Table 7). At the control, the highest CP content was recorded at the $2^{\text {nd }}$ cut, except in 2009 (the $3^{\text {rd }}$ cut). It may be concluded that $\mathrm{CP}$ content was higher at the treatments with the low nutrient ratio than at those with the high one. The results showed that the treatment without fertiliser application could provide the required quality of DM, as reported also by Michalec et al. (2007).

Some authors (Lichner et al. 1983; Krajčovič 1997; Holúbek 1991; Jančovič 1999) point out to the existing difference between the content of minerals in plants and that required by animals which can be mitigated by fertiliser application to grassland. Fiala (2002) reports that the long-term application of fertiliser has influ- 


\section{$\mathrm{T}$ a b 1 e 4}

Crude protein content in dry matter of herbage $[\mathrm{g} / \mathrm{kg}]$

\begin{tabular}{|c|c|c|c|c|c|c|c|c|c|c|c|}
\hline \multirow{3}{*}{ Years } & \multirow{3}{*}{ Cuts } & \multicolumn{10}{|c|}{ Treatments* } \\
\hline & & \multirow{2}{*}{$\begin{array}{l}0 \\
1\end{array}$} & \multirow{2}{*}{$\begin{array}{c}\mathrm{PK} \\
2\end{array}$} & \multicolumn{4}{|c|}{$1: 0.30: 0.80$} & \multicolumn{4}{|c|}{$1: 0.15: 0.40$} \\
\hline & & & & 3 & 4 & 5 & 6 & 7 & 8 & 9 & 10 \\
\hline \multirow{3}{*}{2006} & $1^{\text {st }}$ & 112.67 & 152.00 & 134.90 & 171.34 & 201.68 & 163.03 & 135.29 & 157.59 & 179.27 & 168.82 \\
\hline & $2^{\text {nd }}$ & 134.19 & 94.60 & 137.74 & 137.37 & 148.48 & 124.19 & 134.43 & 123.41 & 123.02 & 130.32 \\
\hline & $3^{\text {rd }}$ & 129.56 & 122.99 & 122.31 & 131.18 & 120.49 & 127.84 & 153.81 & 120.84 & 112.25 & 116.93 \\
\hline \multirow{3}{*}{2007} & $1^{\text {st }}$ & 135.23 & 144.24 & 134.66 & 153.51 & 152.41 & 138.71 & 154.19 & 152.41 & 137.87 & 156.57 \\
\hline & $2^{\text {nd }}$ & 148.73 & 139.94 & 128.73 & 137.58 & 114.21 & 129.14 & 122.40 & 110.77 & 127.52 & 124.25 \\
\hline & $3^{\text {rd }}$ & 120.87 & 116.83 & 116.96 & 127.21 & 137.26 & 136.69 & 117.39 & 125.03 & 118.91 & 124.75 \\
\hline \multirow{3}{*}{2008} & $1^{\text {st }}$ & 112.92 & 130.47 & 124.15 & 129.04 & 123.80 & 115.83 & 122.95 & 118.00 & 116.26 & 119.87 \\
\hline & $2^{\text {nd }}$ & 136.26 & 126.45 & 127.20 & 159.80 & 125.04 & 155.63 & 132.06 & 129.74 & 127.82 & 136.84 \\
\hline & $3^{\text {rd }}$ & 113.86 & 116.61 & 124.36 & 116.32 & 121.58 & 108.59 & 114.49 & 125.51 & 119.71 & 112.50 \\
\hline \multirow{3}{*}{2009} & $1^{\text {st }}$ & 93.75 & 105.43 & 105.89 & 108.05 & 94.94 & 123.82 & 113.31 & 115.57 & 118.90 & 119.00 \\
\hline & $2^{\text {nd }}$ & 128.11 & 123.99 & 122.47 & 128.08 & 124.52 & 134.36 & 131.50 & 141.31 & 148.78 & 129.72 \\
\hline & $3^{\text {rd }}$ & 130.21 & 121.23 & 131.80 & 133.92 & 130.41 & 139.12 & 138.09 & 131.67 & 132.75 & 134.29 \\
\hline \multicolumn{2}{|l|}{ Mean } & 124.70 & 124.57 & 125.93 & 136.12 & 132.90 & 133.10 & 130.83 & 129.32 & 130.25 & 131.15 \\
\hline
\end{tabular}

*see Table 1

T a b 1 e 5

Mean content of minerals $[\mathrm{g} / \mathrm{kg}$ ]

\begin{tabular}{|c|c|c|c|c|c|c|c|c|c|c|c|}
\hline \multirow{3}{*}{ Minerals } & \multirow{3}{*}{ Cuts } & \multicolumn{10}{|c|}{ Treatments* } \\
\hline & & \multirow{2}{*}{$\begin{array}{l}0 \\
1\end{array}$} & \multirow{2}{*}{$\frac{\mathrm{PK}}{2}$} & \multicolumn{4}{|c|}{$1: 0.30: 0.80$} & \multicolumn{4}{|c|}{$1: 0.15: 0.40$} \\
\hline & & & & 3 & 4 & 5 & 6 & 7 & 8 & 9 & 10 \\
\hline \multirow{3}{*}{$\mathrm{P}$} & $1^{\mathrm{st}}$ & 1.95 & 3.31 & 2.49 & 3.00 & 3.30 & 3.04 & 2.08 & 2.07 & 2.47 & 2.45 \\
\hline & $2^{\text {nd }}$ & 2.32 & 3.16 & 2.67 & 3.36 & 3.02 & 3.05 & 2.38 & 2.52 & 2.70 & 2.65 \\
\hline & $3^{\text {rd }}$ & 2.41 & 3.42 & 2.80 & 2.96 & 3.27 & 3.19 & 2.59 & 2.43 & 2.82 & 2.48 \\
\hline \multirow{3}{*}{ K } & $1^{\text {st }}$ & 15.76 & 19.71 & 18.41 & 19.02 & 21.37 & 23.45 & 15.87 & 14.36 & 16.33 & 16.70 \\
\hline & $2^{\text {nd }}$ & 15.43 & 17.04 & 15.52 & 16.64 & 16.88 & 18.78 & 20.18 & 20.47 & 19.71 & 23.25 \\
\hline & $3^{\text {rd }}$ & 13.05 & 13.56 & 13.51 & 13.87 & 14.12 & 15.27 & 14.18 & 12.05 & 12.33 & 12.97 \\
\hline \multirow{3}{*}{$\mathrm{Ca}$} & $1^{\text {st }}$ & 8.29 & 10.80 & 9.49 & 8.25 & 8.04 & 7.49 & 8.41 & 7.86 & 8.37 & 7.85 \\
\hline & $2^{\text {nd }}$ & 10.55 & 10.29 & 13.00 & 13.08 & 8.87 & 13.37 & 16.26 & 10.63 & 12.02 & 13.89 \\
\hline & $3^{\text {rd }}$ & 15.07 & 16.94 & 13.30 & 13.75 & 12.53 & 11.75 & 11.19 & 12.74 & 14.69 & 12.28 \\
\hline \multirow{3}{*}{$\mathrm{Mg}$} & $1^{\text {st }}$ & 2.82 & 3.29 & 2.80 & 2.59 & 2.41 & 2.46 & 3.12 & 3.00 & 3.02 & 2.80 \\
\hline & $2^{\text {nd }}$ & 4.65 & 3.71 & 4.81 & 4.35 & 3.22 & 4.27 & 4.78 & 3.66 & 4.51 & 4.54 \\
\hline & $3^{\text {rd }}$ & 4.42 & 4.58 & 4.67 & 3.84 & 4.35 & 3.85 & 4.28 & 4.10 & 4.37 & 4.35 \\
\hline
\end{tabular}

*see Table 1 


\section{$\mathrm{T}$ a $\mathrm{b} 1$ e 6}

The effect of years on dry matter yield $[\mathrm{t} / \mathrm{ha}]$

\begin{tabular}{|c|c|c|}
\hline Year & $\begin{array}{c}\text { Dry matter yield } \\
{[\mathrm{t} / \mathrm{ha}]}\end{array}$ & SEM \\
\hline 2006 & $6.04^{\mathrm{bc}}$ & 0.212 \\
2007 & $6.30^{\mathrm{c}}$ & 0.302 \\
2008 & $4.39^{\mathrm{a}}$ & 0.414 \\
2009 & $5.81^{\mathrm{b}}$ & 0.434 \\
\hline
\end{tabular}

The values in the same row with different superscript letters are significantly different at $P<0.01$ level for each variable Tukey's HSD test

SEM - standard error of the mean

\section{$\mathrm{T}$ a $\mathrm{b} 1$ e 7}

The effects of fertiliser application, cuts, and years on the nutrient content $[\mathrm{g} / \mathrm{kg}]$

\begin{tabular}{|c|c|c|c|c|c|}
\hline Factor & Crude protein & $P$ & K & $\mathrm{Ca}$ & $\mathrm{Mg}$ \\
\hline \multicolumn{6}{|c|}{ Treatments* } \\
\hline 1 & $124.63^{\mathrm{a}}$ & $2.23^{\mathrm{a}}$ & $14.70^{\mathrm{a}}$ & $11.36^{\mathrm{ab}}$ & $4.10^{\mathrm{ab}}$ \\
\hline 2 & $124.58^{\mathrm{a}}$ & $3.28^{\mathrm{d}}$ & $16.61^{\mathrm{b}}$ & $12.69^{\mathrm{b}}$ & $3.99^{\mathrm{ab}}$ \\
\hline 3 & $126.00^{\mathrm{a}}$ & $2.65^{\mathrm{a}}$ & $15.70^{\mathrm{b}}$ & $11.87^{\mathrm{ab}}$ & $4.29^{b}$ \\
\hline 4 & $136.29^{\mathrm{a}}$ & $3.10^{\mathrm{bc}}$ & $15.39^{\mathrm{b}}$ & $11.67^{\mathrm{ab}}$ & $3.75^{\mathrm{ab}}$ \\
\hline 5 & $133.08^{\mathrm{a}}$ & $3.20^{\mathrm{c}}$ & $17.34^{\mathrm{b}}$ & $9.81^{\mathrm{a}}$ & $3.52^{\mathrm{a}}$ \\
\hline 6 & $133.05^{\mathrm{a}}$ & $3.10^{\mathrm{b}}$ & $19.12^{\mathrm{b}}$ & $10.79^{\mathrm{ab}}$ & $3.66^{\mathrm{ab}}$ \\
\hline 7 & $130.81^{\mathrm{a}}$ & $2.35^{\mathrm{a}}$ & $16.72^{\mathrm{b}}$ & $11.82^{\mathrm{ab}}$ & $4.20^{\mathrm{ab}}$ \\
\hline 8 & $129.06^{\mathrm{a}}$ & $2.33^{\mathrm{a}}$ & $15.64^{\mathrm{b}}$ & $10.38^{\mathrm{ab}}$ & $3.70^{\mathrm{ab}}$ \\
\hline 9 & $129.86^{\mathrm{a}}$ & $2.66^{\mathrm{a}}$ & $16.10^{\mathrm{b}}$ & $11.64^{\mathrm{ab}}$ & $4.11^{\mathrm{ab}}$ \\
\hline 10 & $131.18^{\mathrm{a}}$ & $2.54^{\mathrm{a}}$ & $17.56^{\mathrm{b}}$ & $11.14^{\mathrm{ab}}$ & $4.10^{\mathrm{ab}}$ \\
\hline SEM & 2.385 & 0.065 & 0.790 & 0.541 & 0.169 \\
\hline \multicolumn{6}{|c|}{ Cuts } \\
\hline $1^{\text {st }}$ & $133.71^{\mathrm{b}}$ & $2.62^{\mathrm{a}}$ & $18.12^{\mathrm{b}}$ & $8.48^{\mathrm{a}}$ & $3.03^{\mathrm{a}}$ \\
\hline $2^{\text {nd }}$ & $131.00^{\mathrm{b}}$ & $2.78^{\mathrm{ab}}$ & $18.26^{\mathrm{b}}$ & $12.09^{\mathrm{b}}$ & $4.31^{\mathrm{b}}$ \\
\hline $3^{\text {rd }}$ & $124.93^{\mathrm{a}}$ & $2.83^{\mathrm{b}}$ & $13.49^{\mathrm{a}}$ & $13.42^{\mathrm{c}}$ & $4.28^{b}$ \\
\hline SEM & 1.283 & 0.045 & 0.397 & 0.246 & 0.089 \\
\hline \multicolumn{6}{|c|}{ Years } \\
\hline 2006 & $137.42^{b}$ & $3.02^{\mathrm{c}}$ & $15.42^{\mathrm{a}}$ & $11.06^{\mathrm{a}}$ & $4.77^{\mathrm{b}}$ \\
\hline 2007 & $132.83^{\mathrm{b}}$ & $2.73^{\mathrm{b}}$ & $19.74^{\mathrm{b}}$ & $12.82^{\mathrm{b}}$ & $4.61^{\mathrm{b}}$ \\
\hline 2008 & $124.79^{\mathrm{a}}$ & $2.49^{\mathrm{a}}$ & $14.70^{\mathrm{a}}$ & $10.4^{\mathrm{a}}$ & $3.37^{\mathrm{a}}$ \\
\hline 2009 & $123.88^{\mathrm{a}}$ & $2.73^{\mathrm{b}}$ & $16.49^{\mathrm{ab}}$ & $10.94^{\mathrm{a}}$ & $3.23^{\mathrm{a}}$ \\
\hline SEM & 1.430 & 0.050 & 0.469 & 0.333 & 0.085 \\
\hline
\end{tabular}

The values in the same row with different superscript letters are significantly different at $P<0.01$ level for each variable Tukey's HSD test; SEM - standard error of the mean

*see Table 1

ence on the content of mineral substances in total and at the individual cuts as well. The rising rates of nitrogen fertiliser are increasing the content of $\mathrm{N}, \mathrm{P}$ and $\mathrm{Na}$, but decreasing the content of $\mathrm{Ca}, \mathrm{Mg}$ and $\mathrm{K}$. The threecut utilisation of sward is characteristic of increasing content of $\mathrm{Ca}$ and $\mathrm{Mg}$ and decreasing $\mathrm{K}$ content from 
the first to the last cut.

Mean content of minerals is given in Table 5. Averaged over the research period, the lowest $\mathrm{P}$ content $(1.945 \mathrm{~g} / \mathrm{kg}$ ) was recorded at Treatment 1 (the control). Generally, the P content was low at all the cuts. The highest $\mathrm{P}$ content was found at Treatment 2 in all of the cuts $(3.31,3.16$ and $3.42 \mathrm{~g} / \mathrm{kg}$, respectively) throughout the period of research. Nerušil et al. (2007) also reported that the long-term application of $\mathrm{P}$ and $\mathrm{K}$ fertilisers increases the legume dominance and consequently, also the content of $\mathrm{P}, \mathrm{Ca}$ and $\mathrm{Mg}$. An acceptable content was provided also by the Treatments 4, 5 and 6 with the low ratio of nutrients, respectively.

The lowest potassium content ranging between 13.05 and $15.76 \mathrm{~g} / \mathrm{kg}$ was recorded at the zero-fertilised control. The $\mathrm{K}$ content was decreasing from the $1^{\text {st }}$ to the $3^{\text {rd }}$ cut at the treatments 1 to 6 , respectively. The highest $\mathrm{K}$ content was found in the $2^{\text {nd }}$ cut at Treatments 7 to 10 , the ones with the high nutrient ratio. Similar conclusions are drawn by Ježíková and Lihán (1997) who report that the content of K and P in herbage is increasing at the high nutrient ratio. However, one cannot agree with their statement that the low $\mathrm{N}$ : $\mathrm{P}: \mathrm{K}$ ratio results also in decreased content of $\mathrm{P}$ and $\mathrm{K}$ as well as in increased Ca content.

The highest calcium content was found at Treatment 3 in the $2^{\text {nd }}$ cut. The content of $\mathrm{Ca}$ was increasing with the cuts, except for the Treatments 6, 7 and 10, respectively; the highest $\mathrm{Ca}$ content was found in the $2^{\text {nd }}$ cut. Similar results were reported by Jančovič (1997).

The magnesium content was higher at the treatments with the high ratio of nutrients. The highest $\mathrm{Mg}$ content $(4.81 \mathrm{~g} / \mathrm{kg})$ was found at Treatment 3 in the $2^{\text {nd }}$ cut and moreover, at the same cut, the $\mathrm{Mg}$ content was $4.65 \mathrm{~g} / \mathrm{kg}$ at the zero-fertilised control. Lichner $e t$ al. (1977) and Jančovič (1997) report that Mg content increases with the rising intensity of $\mathrm{N}$ fertiliser application. Table 7 shows the significant effects of the cuts on the mean content of $\mathrm{P}, \mathrm{K}, \mathrm{Ca}$ and $\mathrm{Mg}$.

\section{CONCLUSIONS}

The results of research on the production and quality of herbage in relation to the long-term application rates of fertiliser and the nutrient ratios were concluded as follows:

Over the research period, the highest dry matter production was found at the treatment with the highest $\mathrm{N}(200 \mathrm{~kg})$ rate and the low nutrient ratio applied 1 : $0.3: 0.8$ (total dry matter yield over the four research years was $27.18 \mathrm{t} / \mathrm{ha})$.

The dry matter production was higher at the application of 50 and $100 \mathrm{~kg} \mathrm{~N} / \mathrm{ha}$ fertiliser rates with the high nutrient ratio of $1: 0.15: 0.4$.

The crude protein content was rising with the increasing $\mathrm{N}$ fertiliser rates. The highest crude protein content $(201.68 \mathrm{~g} / \mathrm{kg})$ was found in the $1^{\text {st }}$ cut at the treatment with the rate of $150 \mathrm{~kg} \mathrm{~N} / \mathrm{ha}$.

The low nutrient ratio of $1: 0.3: 0.8$ resulted in high content of $\mathrm{P}, \mathrm{K}$ and $\mathrm{Ca}$, but in low $\mathrm{Mg}$ content in dry matter, respectively.

The content of $\mathrm{K}$ was rising in the $2^{\text {nd }}$ cut and decreasing in the $3^{\text {rd }}$ cut at all the treatments. The content of $\mathrm{Ca}$ was rising to the $3^{\text {rd }}$ cut and the $\mathrm{Mg}$ content was increasing in the $2^{\text {nd }}$ cut at all the research treatments.

Based on the research results, it was concluded that the ratio of $1: 0.30: 0.8$ was more favourable, when considering the needs of animals.

Acknowledgements: The presented research was carried out as a part of the research project of the Plant Production Research Center Pieštany - Grassland and Mountain Agriculture Research Institute Banská Bystrica named „Competitiveness and ecologisation of crop production in the regions of Slovakia through the systems of management on agricultural land and by innovating the constituents of crop growing technologies“, No. UO 27/091 05 01/091 0510.

\section{REFERENCES}

FIALA, J. 2002. Vývoj ekologické a výnosové stability polopř́rodního travního porostu při dlouhodobém hnojení a využívání [Development of ecological and yield stability of semi-natural grassland by its long-term fertilization and utilization]. In Grassland Ecology VI: Proceedings of the International Scientific Conference. Banská Bystrica : VÚTPHP, 10.-11.12.2002, ISBN 80-968890-7-9, pp.124137.

GLĄBA, T. - KACORZYKB, P. 2011. Root distribution and herbage production under different management regimes of mountain grassland. In Soil and Tillage Research, vol. 113, no. 2, 2011, pp. 99-104.

HEJCMAN, M. - SZAKOVÁ, J. - SCHELlBERG, J. TLUSTOŠ, P. 2010. The Rengen Grassland Experiment: relationship between soil and biomass chemical properties, amount of elements applied, and their uptake. In Plant and Soil, vol. 333, pp. 163-179. DOI: 10.1007/s11104-010- 
0332-3.

HOLÚBEK, R. 1991. Produkčná schopnost' a kvalita PTP $v$ mierne teplej a mierne suchej oblasti [The production capacity and quality of oversown grassland in a mild and slightly dry area]. Pol'nohospodárska veda. Bratislava : Veda SAV, 1991, $132 \mathrm{pp}$.

HOLÚBEK, R. - JANČOVIČ, J. - BABELOVÁ, M. 2001. Kvalita sušiny sena $\mathrm{z}$ extenzívne hnojených trávnych porastov [The quality of dry matter in hay made from extensively fertilized grassland]. In Agrochémia, vol. 41, 2001, no.1, pp.16-20.

HOLÚBEK, R. - JANČOVIČ, J. - GREGOROVÁ, H. - NOVÁK, J. - ĎURKOVÁ, E. -VOZÁR, L. 2007. Krmovinárstvo - manažment pestovania a využivania krmovín [Forage production - management of crop-growing and utilisation] 1. vyd. Nitra: SPU, 2007. 420 pp. ISBN 978-80-8069-9116.

HONSOVÁ, D. - SVOBODOVÁ, M. - MRKVIČKA, J. 2006. Dlouhodobé hnojení a jeho vliv na výšku trvalých travních porostů [Influence of long-term fertilization on actual sward height at permanent grassland]. In Grassland - part of mountain agriculture and landscape: proceedings of international scientific conference. SCPV Nitra : VÚTPHP Banská Bystrica, 27.-28.9.2006. ISBN 80-88872-56-1, pp. 241-245.

HONSOVÁ, D. - HEJCMAN, M. - KLAUDISOVÁ, M. - PAVLŮ, V. - HAKL, J. 2007. Species composition of an alluvial meadow after 40 years of applying nitrogen, phosphorus and potassium fertilizer. In Preslia, vol. 79, 2007, no. 4, pp. 245-258.

JANČOVIČ, J. 1997. Mineral substances in natural grassland under different nitrogen fertilizing systems. In Polnohospodárstvo (Agriculture), vol. 43, 1997, no. 3, pp. 207216.

JANČOVIČ, J. 1999. Niektoré aspekty hnojenia trávnych porastov [Some aspects of fertilizer application to grassland]. In Agrochémia, vol. 39, 1999, no. 1, pp. 12-15.

JANČOVIČ, J. - VOZÁR, L. - BAČOVÁ, S. 2009. Effect of high nitrogen dose on floristical composition of grassland phytocenosis. In Acta fytotechnica et zootechnica, vol. 12, 2009 , no. 1 , pp. 17-19.

JEŽÍKOVÁ, O. - LIHÁN, E. 1997. Dlhodobé hnojenie aluviálnej lúky pri dvoch pomeroch $\mathrm{N}$ : P : K [Long-term fertilizer application on an alluvial meadow at two ratios of $\mathrm{N}: \mathrm{P}$ : K]. In Polnohospodárstvo (Agriculture), vol. 43, 1997, no. 4-5, pp. 287-302.

KRAJČOVIČ, V. 1997. Štyri okruhy pät'desiatročných aktivít v odvetví krmovinárstva [Four spheres of fifty-year activities in the field of forage production]. In Ekologické a biologické aspekty krmovinárstva. Nitra : SPU, 1997. pp. 91-103.

LICHNER, S. - MORHÁČ, P. - ŠANTA, M. - FOLKMAN, I. 1977. Lúky a pasienky [Meadows and pastures] 1. vyd. Bratislava : Príroda, 1977, 423 pp.

LICHNER, S. - KLESNIL, A. - HALVA, A.1983. Krmovinárstvo [Forage production] 1.vyd. Bratislava : Príroda, 1983, $551 \mathrm{pp}$.

MICHALEC, M. - VARGOVÁ, V. - KOVÁČIKOVÁ, Z. 2007. Vplyv dlhodobého hnojenia a využívania TTP na kvalitatívne a kvantitatívne aspekty produkcie [Impact of long-term fertilizer application and utilization of permanent grassland on quantitative and qualitative production parameters]. In Grassland Ecology VII : Proceedings of the International Scientific Conference. Banská Bystrica : SCPV Nitra -VÚTPHP Banská Bystrica, 28.-30.11.2007. ISBN 80-8069-721-3, pp. 282-288.

NERUŠIL, P. - KOHOUTEK, A. - KOMÁREK, P. - ODSTRČILOVÁ, V. 2007: Koncentrace a odběr minerálních živin trvalým travním porostem na fluvizemi glejové [Concentration and uptake of mineral nutrients by permanent grassland on Fluvi-eutric Gleysol]. In Multifunctional management and utilization of permanent grasslands in : proceedings from international scientific conference. Rapotín : VÚCHS, 13.11.2007. ISBN 978-80-87144-00-8, pp. $164-168$.

RATAJ, D. 1996. Trvalé trávne porasty [Permanent grassland] In KNOTEK, S. et al.: Príručka krmovinára. Banská Bystrica : VÚTPHP Banská Bystrica, 1996. 258 pp.

SLAMKA, P. - HANÁČKOVÁ, E. - HOLÚBEK, I. 2006. Vplyv hnojenia trávnych porastov na úrodu sušiny a dusíkatých látok [Dry matter and crude protein yields in fertilized grassland]. In Scientia Agriculturae Bohemica, vol. 37, 2006, no. 2, pp. 49-57.

VELICH, J. 1986. Studium vývoje produkční schopnosti trvalých lučních porostů a drnového procesu při dlouhodobém hnojení a jeho optimalizace [Study of permanent grassland productivity at long-term fertiliser application and its optimisation] Praha: Videopress MON., 1986, 162 pp.

VOZÁR, L. 2009. Možnosti využitia prerušovanej výživy dusíkom v mätonohovo-hrebienkovom trávnom poraste [Possibilities of using interrupted nitrogen nutrition in the LolioCynosuretum type of grassland.] 1.vyd. Nitra: SPU, 2009. 84 pp. ISBN 978-80-552-0211-2.

WHITEHEAD, D.C. 2000. Nutrients elements in grassland: soil - plant - animal relationships. Wallingford, UK : CABI Publishing, 2000. 369 pp. ISBN 0-85199-437-7.

Received: January, $25^{\text {th }}, 2011$ 